\title{
The future of Dutch housing associations
}

\author{
Peter J. Boelhouwer
}

Received: 16 August 2007 / Accepted: 16 August 2007 / Published online: 3 September 2007

(C) Springer Science+Business Media B.V. 2007

\begin{abstract}
This paper discusses the future of the social rented sector in the Netherlands. There are several reasons why the position of this sector is currently under close scrutiny. Whereas attention to social rented housing had lapsed by the start of this century, the growing housing shortage and stagnation in the restructuring of older urban areas brought this sector back into the political spotlight. Also the European Commission is having a major impact on the future position of the sector. The Commission has ordered the Dutch Government to establish a level playing field by abolishing the privileges of the housing associations. Against this background, this paper discusses the possible tasks and proper functioning of the Dutch housing associations.
\end{abstract}

Keywords Netherlands $\cdot$ Housing associations $\cdot$ Housing policy

\section{Introduction}

The housing system of the Netherlands has acquired an international reputation because of its special nature and the way it has evolved. Many other countries that have been attempting to transform their housing system are taking their cue from recent developments in the Netherlands. Over the past few years, the Dutch housing system has been a source of inspiration for policy-makers far and wide, including scholars and officials from some of the former socialist states in Eastern Europe and several Asian nations. Researchers and policy-makers in those countries have shown keen interest in the way social rented housing is operated in the Netherlands. In particular, they are intrigued by the strong position of social housing in this country: $44 \%$ of the total housing stock of the Netherlands was accounted for by this sector at the beginning of the 1990s. The Netherlands clearly stands out in this sense; the share of this sector in most other West European countries rarely reaches $20 \%$. The strong position of Dutch social housing has its roots in the long period during which

P. J. Boelhouwer $(\bowtie)$

OTB Research Institute for Housing, Urban and Mobility Studies, Geo-information and Land Development, Delft University of Technology, P.O. 5030,

2600 GA Delft, The Netherlands

e-mail: P.J.Boelhouwer@tudelft.nl 
housing was influenced by the national government. Of course, public intervention had been common practice throughout the region for decades. However, the Netherlands eventually came to steer its own course. Whereas most other West European countries veered toward privatisation in the early 1970s, the Netherlands did not start to move in that direction until the 1990s.

In this contribution, we shall take a close look at the present policy debate about the future role of the Dutch social rented sector. Section 2 will discuss the positions of a number of important players: the Government, the social sector landlords and the European Commission. The positions adopted by these players determine the future development of the Dutch social rented sector. In fact, their positions were one of the things that prompted the Dutch Government to send a letter to Parliament in late 2005 outlining a policy vision on the future of the housing associations (Dekker 2005). Section 3 will deal with the most important proposals contained in this letter. We will then give a brief evaluation of the proposed policy (Sect. 4), based on recommendations issued by the Ministry of Housing, Spatial Planning and the Environment council (VROM-raad) in (2005). In Sect. 5 we shall take a detailed look at a number of issues that have not yet been fully resolved. These are not only of interest in terms of Dutch policy, but also are currently the subject of much discussion in several West-European countries thanks to the recent stand taken by the European Commission.

\section{Differing visions of how housing associations function}

In its recommendations 'Look back or look forward?' the Ministry of Housing, Spatial Planning and the Environment council typifies the current situation in the housing association sector as follows:

- The current pressure on the housing market puts associations in a strong position. The rentability of their housing is excellent. A few years ago they worried about empty accommodation, whereas now supply exceeds demand right across the board.

- Towards the end of the 1990s, national Government stated that new housing production should concentrate on the market sector. As a result, the associations have built very little social rented housing during the past 5 years. This has created a gap between the need for social rented housing and the actual building.

- The financial position is robust. More capital has been accrued than the minimum amount needed, creating room for investment. The composition of the housing supply (age, quality), the development of demand on the housing market and the shift in the attitude of national Government all point towards the need for a substantial investment programme. There are huge differences in the financial positions of the various associations.

- The image of the sector is decidedly poor. Much of the publicity is negative in tone (high salaries, arrogance, low housing production).

- The European Union is asking for attention to be paid to a fair competitive position in relation to commercial landlords and project developers, and to the size of the target group of the social rented sector.

On the basis of these characteristics, one can conclude that the housing associations have become used to not being held accountable for their actions. The organisations have become distanced from their 'natural owners', the tenants and the Government, and they are neither 'disciplined by the market' nor 'disciplined by the Government'. There is as yet 
no structural incentive for the associations to make socially acceptable investments. It's important to realise that in practice, housing associations are making a lot of socially acceptable investments. The amount of the investments and the direction are however not controlled or steered by government bodies. On the other hand, most associations feel stifled by the State-dictated policy framework and the legislation and regulations. They find themselves trapped in a bureaucratic web and would like more room for enterprise. In order to face up to the problems described above, a deluge of reports and recommendations appeared in the Netherlands in the period 2004-2006. Alongside all these reports and recommendations, the recent stance adopted by the European Commission is just as significant in terms of the future positioning of the housing associations. Within the context of the European regulations on market efficiency and competition, all forms of State assistance that cannot be termed a service of general interest must in principle be reported to the European Commission. In this respect the European Commission's decision of 13 July 2005 to grant the housing sector a general exemption from the obligation to report State assistance is an important one. This 'exemption from notification' can be given because, according to the European Commission, there is only a very limited risk of causing disruption on the internal European market. This means that associations do not have to report every project they undertake involving State assistance to the European Commission. Another condition specified in the decision is that associations must make an administrative distinction for any activities undertaken that do not benefit the public interest. The decision applies to all Member States. One day later, on 14 July 2005, Minister Dekker received a supplementary letter from the European Commission. In this letter, the European Commission indicated that it considers the financing of housing associations in the Netherlands to be a form of existing support. In other words, it is seen as support that was in place prior to 1957 and which is therefore not subject to debate with retrospective effect. All forms of existing support will however be subject to continued scrutiny in respect of developments on the common market. The European Commission can advise Member States of the measures they should take to preserve the qualification 'existing support' for the future.

The European Commission then assessed the support given to the associations in terms of compatibility with the European regulations on the common market. The Commission is of the opinion that the Dutch Government should introduce the following three measures:

- Housing associations activities with State assistance should not only be directly linked to the maximum value of houses, but also to socially deprived households;

- Any commercial operations undertaken by the housing associations should be subject to market conditions, and profits made from commercial activities must be reinvested in the social housebuilding sector;

- Excessive and structural over-capacity of social housing should be prevented by selling these houses, and the over-capacity should be restricted to a small percentage of the total housing supply.

\section{The policy vision of the former Minister of Housing, Spatial Planning and the Environment (VROM)}

Partly on the basis of several reports and recommendations that appeared (Commissie De Boer 2005; Commissie Leemhuis 2005; RIGO 2005, Sociaal Economische Raad 2005; Wetenschappelijke Raad voor het Regeringsbeleid 2004, Wetenschappelijke Raad voor het Regeringsbeleid 2005) in December 2005 former Minister Dekker sent her policy vision on 
the future of housing associations to the Dutch parliament (Dekker 2005). She cites the safeguarding of the associations' achievements and the deployment of their socially-linked capital as the most important targets, along with expanding the potential for social enterprise. The former Minister gives preference to self-steering rather than detailed regulation and sees regulatory monitoring as the final element. Internal monitoring is particularly important to the functioning of the housing associations. The former Minister observes that associations have been fulfilling a crucial role in public housing for more than a century. They should play their part in fulfilling the social commitment with regard to housing. This is the essence of their value and legitimacy.

She sees broad-based responsibility for housing as the associations' basic mission. This means good housing and a well-considered approach to residential areas, in the interests of a well-balanced mix of residents and good living conditions.

The associations have been given two concrete tasks: the primary allocation of regulated rented housing to targeted income groups and investment in housebuilding and restructuring. The primary allocation to targeted income groups is nothing new. However, the former Minister's more flexible definition of the 'targeted income groups' could be referred to as something of a silent revolution. At present, this group includes households with a maximum income between 17,000 and 25,000€ (depending on age and composition). This income bracket is suddenly being raised to around $33,000 €$. Households in social rented accommodation that receive an increase in their income are not directly obliged to move. New housing should provide a sufficiently attractive alternative for these people, according to the former Minister. She also considers the fact that the associations provide housing (particularly in older parts of towns) for households outside the targeted income group to be in the interests of society as a whole.

The aim that associations should make sufficient investments in housebuilding and restructuring is new. The former Minster has linked a housebuilding target of 111,000 houses by 2010 to this objective. If associations build or restructure below these targets, they will be accountable to the municipal authority or (in the second instance) the State. To simplify this process, an 'investment target' has been defined. This is intended to clarify the level of investment that an individual associations can reasonably be expected to make in housebuilding, rebuilding and/or renovations over a period of 4-5 years. She wants to define this further by specifying a percentage of the association's capital or a particular component of its capital.

The former Minister is happy for associations to undertake any number of activities and investments, as long as there is a direct or indirect link with the development or the retention of the value of the association's stock of residential property. This also includes the development of commercial property for societal organisations like schools and hospitals (assuming a link with the neighbourhood) and numerous activities designed to improve the living conditions. The deployment of services such as care, welfare, education and crime prevention will be reserved for other parties.

The former Minister also makes a proposal for defining the activities with and without State assistance. Building, renting, maintaining, renovating and selling housing to households with an annual income of approximately 33,000€ will count as social activities for which State assistance may be granted. This also applies to activities concerned with improving the living conditions and quality of life in as far as this relates to regulated owner-occupier housing. A new factor is that the building, renting and maintenance of social property designated for institutions with a social function can now also be included as activities with State assistance. This distinction between activities with and without State assistance is necessary to make the Dutch social housing system 'Europe-proof'. She gives 
preference to a legal distinction rather than an administrative distinction, as long as the integral direction of the associations' investments can be guaranteed. This point is being looked into. As from 2006, association tax will have to be paid for commercial activities. These proposals are still in line with the idea of the revolving fund principle. Although the profits will be less after taxation, the mother company that is in charge of the social activities can still use them for social activities. The housing association is after all the only shareholder of the 'free' subsidiary company.

Alongside this distinction, the former Minister also wants to allow 'free' subsidiary companies without restrictions on their working domain. She wants to set a maximum limit on the total amount of capital that associations can invest in their 'free' subsidiaries.

Finally, former Minister Dekker wants to allow every association nationwide access, on the condition that the association has first made sound achievement agreements in the municipality or municipalities in which it owns a substantial amount of property.

The former Minister expects the municipal authorities to draw up a vision on housing, including an investment plan. The associations can then produce an 'investment bid' for the local housing specification. This should result in concrete, multi-annual achievement contracts between municipal authorities and associations. If the parties fail to agree, they can opt for mediation. If this fails, the Minister will decide on the situation herself. She will have the option of imposing sanctions on the association or calling the municipal authority to account.

The former Minister wants to reinforce the stakeholders' role of the tenants in the regulations, but has decided against the right of initiative and the right of approval for tenants with regard to investment.

The former Minister expects the sector to take a number of binding steps during the coming period (benchmarking, visitation, professionalisation, internal monitoring and stakeholders' consultations). She will deliberate on external monitoring depending on the speed at which the sector proceeds.

Not all of the proposals of former Minister Dekker were acceptable for the members of parliament. More specifically, the limit of 33,000€ was under debate. After the parliamentary debate, former Minister Dekker agreed to make to some adjustments in the policy letter. But because of the resignation of former Minister Dekker in the spring of 2006 and general elections called for March, the policy development was heavily delayed. Interim Minister Winsemius, who was only in charge for half a year and was actually in a caretaker position for most of the time, did not act on this policy item but concentrated his efforts on the urban restructuring policy. This theme was one of the big issues at the general elections in March 2006. For the new cabinet, the restructuring of 40 selected problem areas in the bigger cities was also one of the spearheads. In July 2007, the new Minister presented her policy vision (Vogelaar 2007). The housing associations play a crucial role in this policy document. The cabinet asked the housing associations to provide 750,000 million euros per year ( 3 billion euros for a period of 4 years). This funding should be added to the plans the housing associations had already agreed on with the municipalities. The final responsibility for this investment fund is in the hands of the Minster of Housing, Communities and Integration. In practice, the steering of the fund should be conducted by the municipalities, the housing associations and the Minister. Until the summer of 2007, however, there was no agreement between the housing associations and the Minister about the total amount of money, which neither should be spent by the housing associations, nor about responsibility for the spending. The Minister and the housing associations took time out of the negotiating process, and agreed to start up the discussion after the summer of 2007. For the discussion about the future role of the housing associations, this new urban restructuring policy is of 
great importance. The housing associations, and more specifically their financial reserves, will largely determine the success of this new government policy. So probably after sorting out the dispute about the role and the duties of the housing associations in this new urban restructuring policy, the discussion that had started under former Minster Dekker on the role and the position of the housing associations in general will be picked up again. The new role of the housing associations in the urban restructuring policy will also affect the policy discussion about the position of the social rented sector. Housing associations are increasingly being asked by central government and municipalities to engage in a broad range of activities such as building schools and hospitals and participating in welfare and employment projects. It's therefore likely that the working domain of the housing associations will further expand in the near future. This will add fuel to the debate between the Dutch Government and the European Commission. Because of this still ongoing debate, the proposals of former Minster Dekker will be in discussion in Dutch politics for the coming months.

\section{Evaluation of the intended policy}

First of all, the fact that the proposals will guarantee the legitimacy of the associations is a positive step. Now that the central government has stated that the associations are part of the common good with responsibility for duties relating to housing, all debate on the associations' right of existence should be a thing of the past. In its recommendations, the Ministry of Housing, Spatial Planning and the Environment council (VROM-raad) also emphasises the crucial role the associations play in the housing market. This is a role that government and the commercial parties often cannot or do not want to take on. It enables the associations to contribute to the stability of the housing market, to help combat risk selection and to create possibilities for access to and movement within the market for groups that would otherwise be unable to accomplish this.

Second, we note that former Minister Dekker endorses a broad social rented sector and holds the values of the mature social housing system in high esteem. Relaxing the income limits for the targeted income group is a step in that direction. These groups were on the verge of drying up as the income limit has only been adjusted by the rate of inflation since 1990, and not by the nominal wage trends. However, the group of households that now has to rely on the social sector is much larger than the (old) targeted income group. The fact that many of them are living in cheap rented housing, while their income is rising above that of the (old) targeted income group has caused them to be labelled as 'profiteers' and wrongful occupiers. Following this logic through, they should be moving to more expensive rented housing or buying their own homes. However, in many cases this is not financially feasible because their income is not high enough to get a mortgage. Raising the income limit for the targeted income group should put an end to the (often digital) discussions about people living in cheap housing to which they are not entitled.

Third, it is positive that the former Minister really seems to be taking her responsibility for the system and keeping a number of sanctions in reserve. The option of dismissing the Supervisory Board for poor performance is new.

Finally, we note the acknowledgement that regional differences exist and that the former Minister is providing room for customised work, geared to the local and regional social specifications. The former Minister's critical attitude towards growth in scale should also be noted. The Ministry of Housing, Spatial Planning and the Environment council has also 
stated that growth in scale will not necessarily lead to a more effective deployment of social capital. Moreover, social embeddedness and growth in scale can be at odds with each other.

\section{Issues yet to be resolved}

Despite the many policy recommendations, all the research and the various policy documents from the former Minister of Housing, Spatial Planning and the Environment as well as the European Commission, there are still a number of interesting issues that need to be resolved during the coming period via debate and study. These questions are also relevant for Minister Vogelaar, who came in power in the autumn of 2006. Actually since the letter of former Minister Dekker was refused by the Dutch parliament at the beginning of 2006 and the European Commission did not react to the reply former Minister Dekker sent to the Commission, the dispute is more or less in an impasse. To conclude this contribution, we shall take a closer look at the most important issues, which still have to be resolved.

First of all, there is the question of the subsidiarity principle (public housing is a matter for the individual Member States) versus the EU policy on competition. Even more fundamental is the question of whether the Netherlands should be allowed to shape its own welfare state and if so, under which conditions. As previously stated, the European Commission has set three conditions for the continuance of the housing associations. The most important question that needs answering is what the term 'socially deprived groups' actually means. Can the Netherlands decide this for itself and, as suggested by former Minister Dekker for example, raise the income limit to 33,000€, or should we be thinking of the much smaller group of households that have to live on minimum wage? The letter from the European Commission appears to be pointing to this last group, while in various verbal explanations, EU commissioner Kroes takes the chill out of the air by indicating that if supported by sound arguments, the Netherlands is free to set this limit as it sees fit.

The second issue concerns the way in which a distinction is made between commercial activities for the market and core activities (so-called general interest services, such as those defined in the Altmark ruling). This distinction is necessary to comply with a second requirement from the European Commission, which states that any commercial activities undertaken by housing associations must be carried out under market conditions (level playing field) and that profits obtained from commercial activities must be reinvested in social housebuilding. The current formulation needs to be worked out more precisely, which raises the question of whether the high limit of $600 €$ currently used for the purposes of determining exemption from association tax will be accepted by the European Commission. The distinction between activities with and without State assistance also raises a number of questions. For instance, one could question whether building an owner-occupied house for the targeted income group should not count as an activity with State assistance. There is also the question of how the Minister of Housing, Spatial Planning and the Environment intends to deal with an integral area-oriented approach involving communal ground and building development. How does one distinguish between activities with and without State assistance in such situations? Another matter that could cause confusion is the two types of subsidiary companies: the subsidiary (activities without state assistance) that is covered by state regulation and direction, and the 'free' subsidiary. The construction that has been chosen is very complicated. It remains to be seen whether associations can and want to achieve the same market yields as the commercial parties in all areas.

Finally, there is no indication as to what would happen if the commercial subsidiary were to go bankrupt. Can the parent company also be held responsible? 
A third interesting legal issue that still needs to be resolved concerns the matter of who actually owns the associations. According to current legislation (the Subsidised Rented Sector (Management) Decree), the associations are private organisations with a social duty, so-called hybrid organisations. Housing associations are therefore not government organisations, but they are not pure market parties either. In this respect it is interesting to look into who is able to exert influence on the sizeable assets of the associations. The advice of the Council of Economic Advisers is to give the housing associations a choice: either stay inside the system with strict regulation and monitoring, or step out of the social system and accept the creaming off of assets by the Government (REA 2006). In the case of this last option, it is not certain whether the Government is actually authorised to dispose of a private organisation's assets unilaterally. In the past, associations have applied for admission as fully private organisations, thereby allowing them to receive subsidies. In exchange, they would offer their rented housing under the cost price. However, they never came to an agreement about putting their capital at the disposal of the Government. In the same way as private property investors, the associations mainly accrued this capital as a result of the increase in the value of their property.

A fourth interesting legal issue is the question of the legal basis of a social enterprise. We are assuming that the hybrid structure will be left intact. The current situation, which lacks any kind of specific regulations, obviously leaves room for improvement. In practice, in many associations the urge for professionalism tends to push idealism aside. The legal design of an association has no rules on the designated use of any excess or surplus. The only restriction is that the surplus should be spent on housing related activities. In order to address this issue, former Minister Dekker has announced an investigation to explore possible designs for a new legal basis for social enterprises.

A fifth interesting organisational problem that still needs resolving is how best to organise the matching of tasks and resources. The Minister has suggested defining housebuilding targets as an incentive for associations to invest. In this way, she is elevating building and restructuring from a means to an objective in itself. The hidden danger here is that during the deliberations the associations are supposed to make, the quality and requirements of the customer may become less important than the realisation of the figures. A housebuilding target could also allow associations to deploy the capital earmarked for social enterprise ineffectually. A 'rich' association would make substantial investments in its own municipality or region, although the social specifications do not really warrant this. The municipality concerned will not be swift to complain. After all, why would a municipality ask a substantial investor to invest money elsewhere? In order to resolve these problems, the Ministry of Housing, Spatial Planning and the Environment council is in favour of a binding arrangement for matching, preferably with a public basis. A periodical capital-dependent levy would be an option, whereby associations could apply for exemption in line with the level of their own investment in new building, urban development and housing and care tasks.

Finally, organising the commercial subsidiaries according to legal or administrative divisions of activities with state assistance has led to an interesting dispute. Both constructions have advantages and disadvantages. The advantage of an administrative distinction is that it provides a clear structure for monitoring and responsibility. Forming a commercial subsidiary involves the risk of becoming politically detached from the parent company, thereby compromising the monitoring and responsibility tasks. On the other hand, an administrative distinction could lead to improper assistance from the parent company leaking into the commercial activities. 


\section{Conclusions}

To our mind, the policy vision of the Minister for Housing, Spatial Planning and the Environmental Dekker is a step towards tackling the current unaccountable position of the association sector. We do not consider housing associations to be an outdated concept: housing involves major social tasks, whereby the efforts and social assets of the associations are indispensable. This policy document allows us to put the discussions on legitimacy and wrongful occupancy behind us.

However, a lot depends on how the policy is worked out in practice. We must keep a close eye on a number of matters:

- Avoidance tactics on the part of the associations (and the municipal authorities) must be firmly dealt with;

- Associations will have to earn their legitimacy by showing themselves to be open to influence from outside. Visitation and transparency are important factors;

- The State will have to stop focusing on numbers. The 'best association' cannot be judged according to the numbers of demolitions, sales and houses built. Tenants, municipal authorities and other stakeholders are in a better position to make this judgement.

Bearing all this in mind, we feel that the associations should be encouraged to look to the future. The sector has been granted respite by the former Minister in order to take a number of binding steps (benchmarking, visitation, professionalisation internal monitoring and stakeholders' consultations). The question is, how long will the new Minister give them?

\section{References}

Commissie De Boer (2005). Lokaal wat kan, centraal wat moet, Hilversum/Den Haag.

Commissie Leemhuis (2005). Zeggenschap en versterking positie huurders(-organisaties), Amsterdam/Den Haag.

Dekker, S. (2005). Beleidsvisie toekomst van woningcorporaties. Brief aan de Tweede Kamer. Den Haag: vergaderjaar 2005/2006, 29 453, nr.30.

RIGO Research en Advies BV (2005). Woningcorporaties: Naar een duidelijke taakafbakening en een heldere sturing, Amsterdam.

REA (2006). Over goede intenties en de harde wetten van de woningmarkt, Den Haag.

Sociaal Economische Raad (2005). Ondernemerschap voor de publieke zaak, Den Haag.

VROM-raad (2005). Voorbij of vooruit? Woningcorporaties aan zet. Den Haag: VROM-raad.

Vogelaar (2007). Actieplan krachtwijken, van aandachtswijk naar krachtwijk, Den Haag, Ministerie VROM. Wetenschappelijke Raad voor het Regeringsbeleid (2004). Bewijzen van goede dienstrverlening, Den Haag. Wetenschappelijke Raad voor het Regeringsbeleid (2005). Vertrouwen in de buurt, Den Haag. 